\title{
UCRL-TR-113867-12
}

LAWRENCE LIVERMORE NATIONAL LABORATORY

\section{LLNL NESHAPs}

2011 Annual Report

Wilson, $K$.

Bertoldo, N.

Gallegos, G.

MacQueen, $D$.

Wegrecki, $A$.

\section{June 2012}


This work performed under the auspices of the U.S. Department of Energy by Lawrence Livermore National Laboratory under Contract DE-AC52-07NA27344. 


\section{U.S. Department of Energy Radionuclide Air Emission Report for 2011}

(in compliance with 40 CFR 61, Subpart H)

Site Name: $\quad$ Lawrence Livermore National Laboratory

Operations Office Information

Office: $\quad$ U.S. Department of Energy

Livermore Site Office

Address: $\quad 7000$ East Avenue, L-293

Livermore, CA 94551

$\begin{array}{llll}\text { Contact: } & \text { Vijay Mishra } & \text { Phone: } & \text { (925) 423-8163 }\end{array}$

Site Information

Operator: Lawrence Livermore National Security, LLC

Address: $\quad 7000$ East Avenue, L-626

Livermore, CA 94551

$\begin{array}{llll}\text { Contact: } & \text { H. Bruce Schultz } & \text { Phone: } & \text { (925) 423-3978 }\end{array}$ 


\section{Table of Contents}

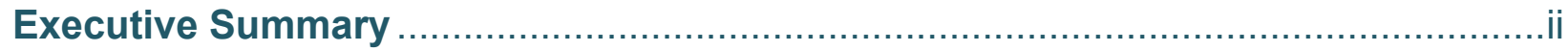

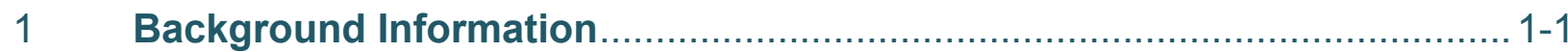

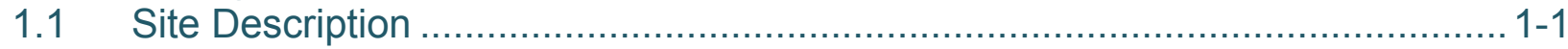

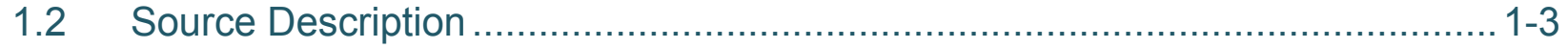

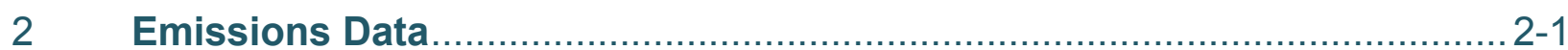

2.1 Major Sources: Measured Emissions ....................................................... 2-1

2.2 Minor Sources: Ambient Measurement Comparison................................... 2-4

2.3 Minor Sources: Source Term Estimate ……......................................... 2-4

2.4 Minor Sources: Open Air Tests .............................................................. 2-5

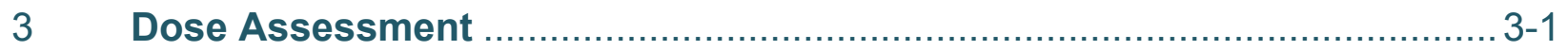

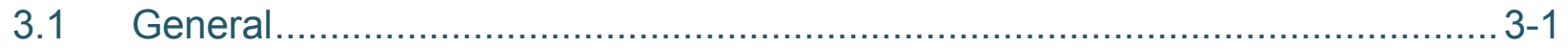

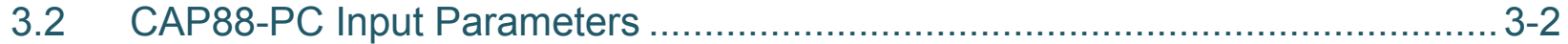

3.2.1 Building-Specific Parameters .................................................................. 3-2

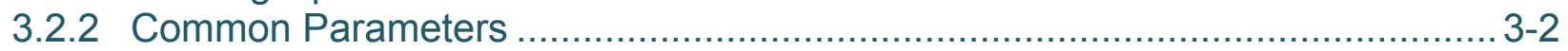

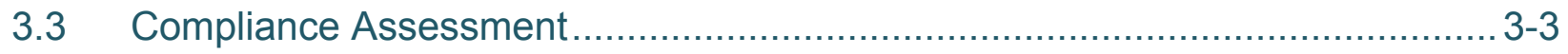

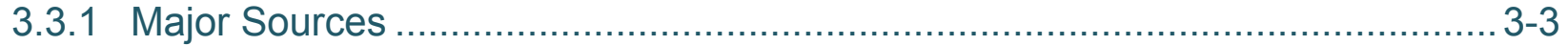

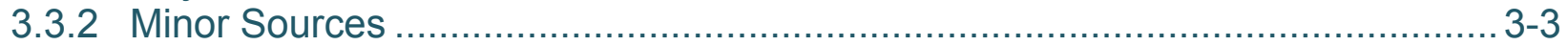

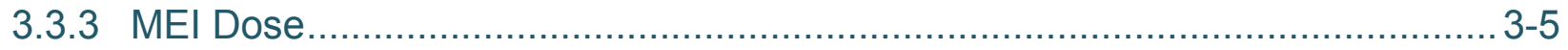

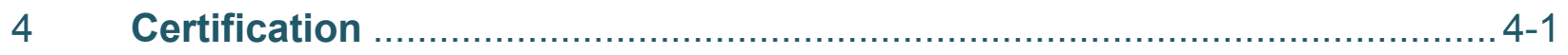

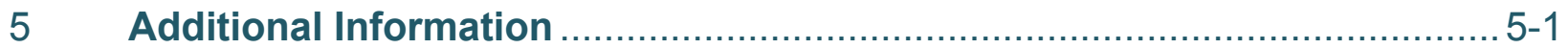

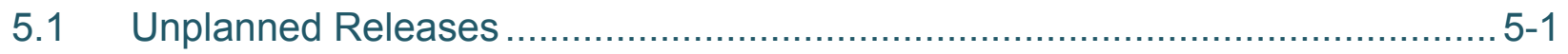

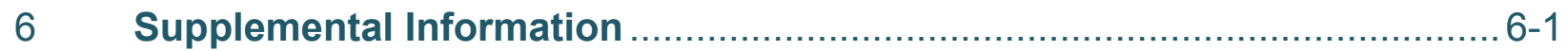

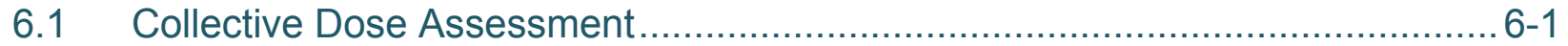

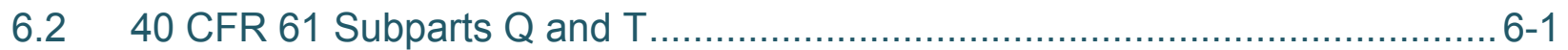

6.3 Periodic Confirmatory Measurement ........................................................ 6-1

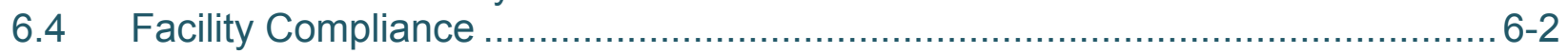

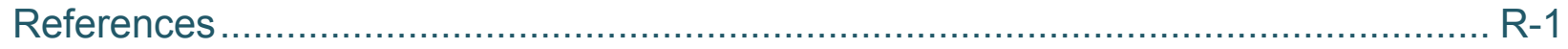

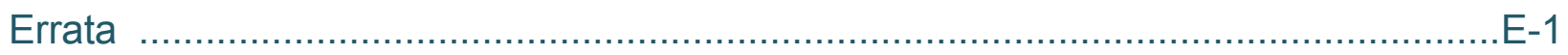

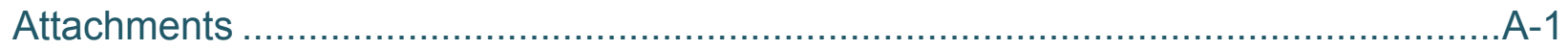

Attachment 1: 2011 LLNL NESHAPs Annual Report Spreadsheet .........................A-2

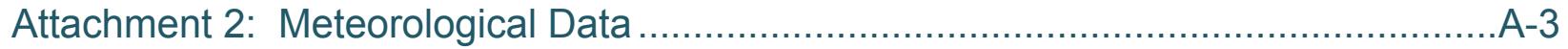

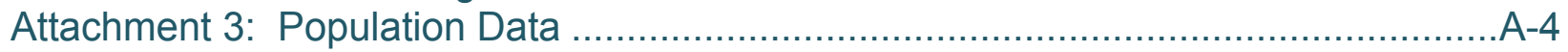


Lawrence Livermore National Security, LLC operates facilities at Lawrence Livermore National Laboratory (LLNL) where radionuclides are handled and stored. These facilities are subject to the U.S. Environmental Protection Agency (EPA) National Emission Standards for Hazardous Air Pollutants (NESHAPs) in Code of Federal Regulations (CFR) Title 40, Part 61, Subpart $\mathrm{H}$, which regulates radionuclide emissions to air from Department of Energy (DOE) facilities. Specifically, NESHAPs limits the emission of radionuclides to the ambient air to levels resulting in an annual effective dose equivalent of $10 \mathrm{mrem}(100 \mu \mathrm{Sv})$ to any member of the public. Using measured and calculated emissions, and building-specific and common parameters, LLNL personnel applied the EPA-approved computer code, CAP88-PC, Version 1.0, to calculate the dose to the maximally exposed individual member of the public for the Livermore site and Site 300.

In 2011, LLNL maintained its compliance with 40 CFR 61, Subpart H. All emissions resulted in calculated doses well below the annual $10 \mathrm{mrem}(100 \mu \mathrm{Sv})$ site-wide standard. The annual doses to the site-wide maximally exposed individual member of the public at the Livermore site and Site 300 from operations in 2011 are:

- Livermore site: $0.017 \mathrm{mrem}(0.17 \mu \mathrm{Sv})$

- Site 300: $9.0 \times 10^{-8} \mathrm{mrem}\left(9.0 \times 10^{-7} \mu \mathrm{Sv}\right)$ 


\section{1 \\ Background Information}

LLNL is a premier research laboratory that is part of the National Nuclear Security Administration (NNSA) within DOE. As a national security laboratory, LLNL is responsible for ensuring that the nation's nuclear weapons remain safe, secure, and reliable. The Laboratory also meets other national security needs, including countering the proliferation of weapons of mass destruction and strengthening homeland security, and conducts major research in atmospheric, earth, and energy sciences; bioscience and biotechnology; and engineering, basic science, and advanced technology. The Laboratory serves as a scientific resource to the U.S. government and a partner to industry and academia.

Because LLNL is a DOE facility, it is subject to the requirements of 40 CFR 61 , Subpart $\mathrm{H}$, National Emission Standards for Emissions of Radionuclides Other Than Radon From Department of Energy Facilities. This regulation limits emissions of radionuclides to ambient air to levels resulting in an annual effective dose equivalent of $10 \mathrm{mrem}(100 \mu \mathrm{Sv})$ to any member of the public. The regulation also requires annual reporting of the emissions and resulting dose.

\subsection{SITE DESCRIPTION}

LLNL consists of two sites-an urban site in Livermore, California, referred to as the "Livermore site;" and a rural experimental test site, referred to as "Site 300," near Tracy, California (Figure 1).

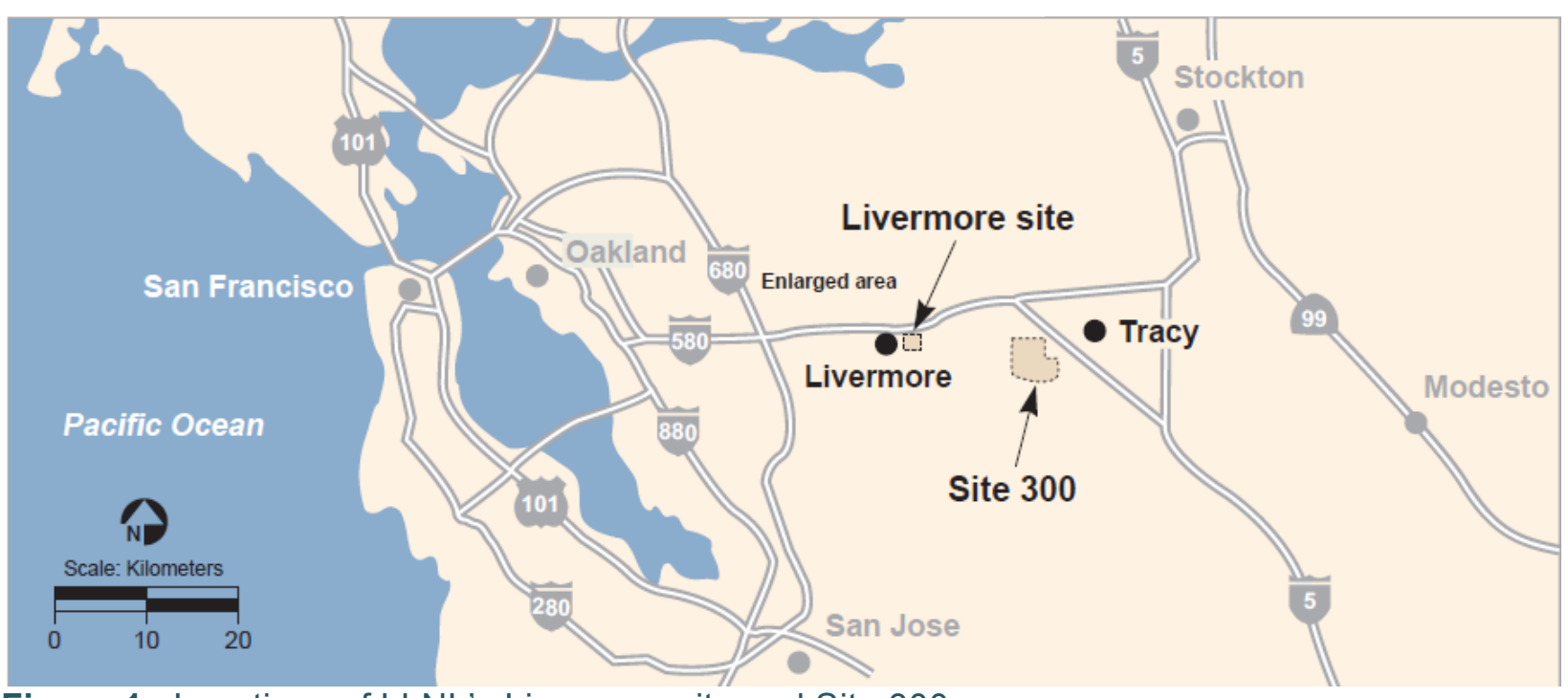

Figure 1. Locations of LLNL's Livermore site and Site 300. 
The Livermore site is just within the eastern city limits of Livermore, a city of about 80,000 in Alameda County. The site occupies 1.3 square miles, including the land that serves as a buffer zone around most of the site. Within a 50-mile radius of the Livermore site are communities such as Tracy and Pleasanton and the more distant (and more densely populated) cities of Oakland, San Jose, and San Francisco. Of the 7.7 million people within 50 miles of the Laboratory, only about $10 \%$ are within 20 miles.

Site 300, LLNL's Experimental Test Site, is located in the Altamont Hills of the Diablo Range and straddles the San Joaquin and Alameda county line. The site is 12 miles east of the Livermore site and occupies 10.9 square miles. The city of Tracy, with a population of over 80,000 , is approximately 6 miles to the northeast (measured from the northeastern border of Site 300 to Sutter Tracy Community Hospital). Of the 7.1 million people who live within 50 miles of Site $300,95 \%$ are more than 20 miles away in distant metropolitan areas such as Oakland, San Jose, and Stockton.

The weather conditions at the Livermore site and Site 300 are very similar. The climate at both sites is best described as Mediterranean, characterized by mild, rainy winters and warm-to-hot, dry summers. However, the complex topography of Site 300 does influence local wind and temperature patterns. The stronger winds that occur at the higher elevations of Site 300 (see Figure 2), results in warmer nights and slightly cooler days than the Livermore site.
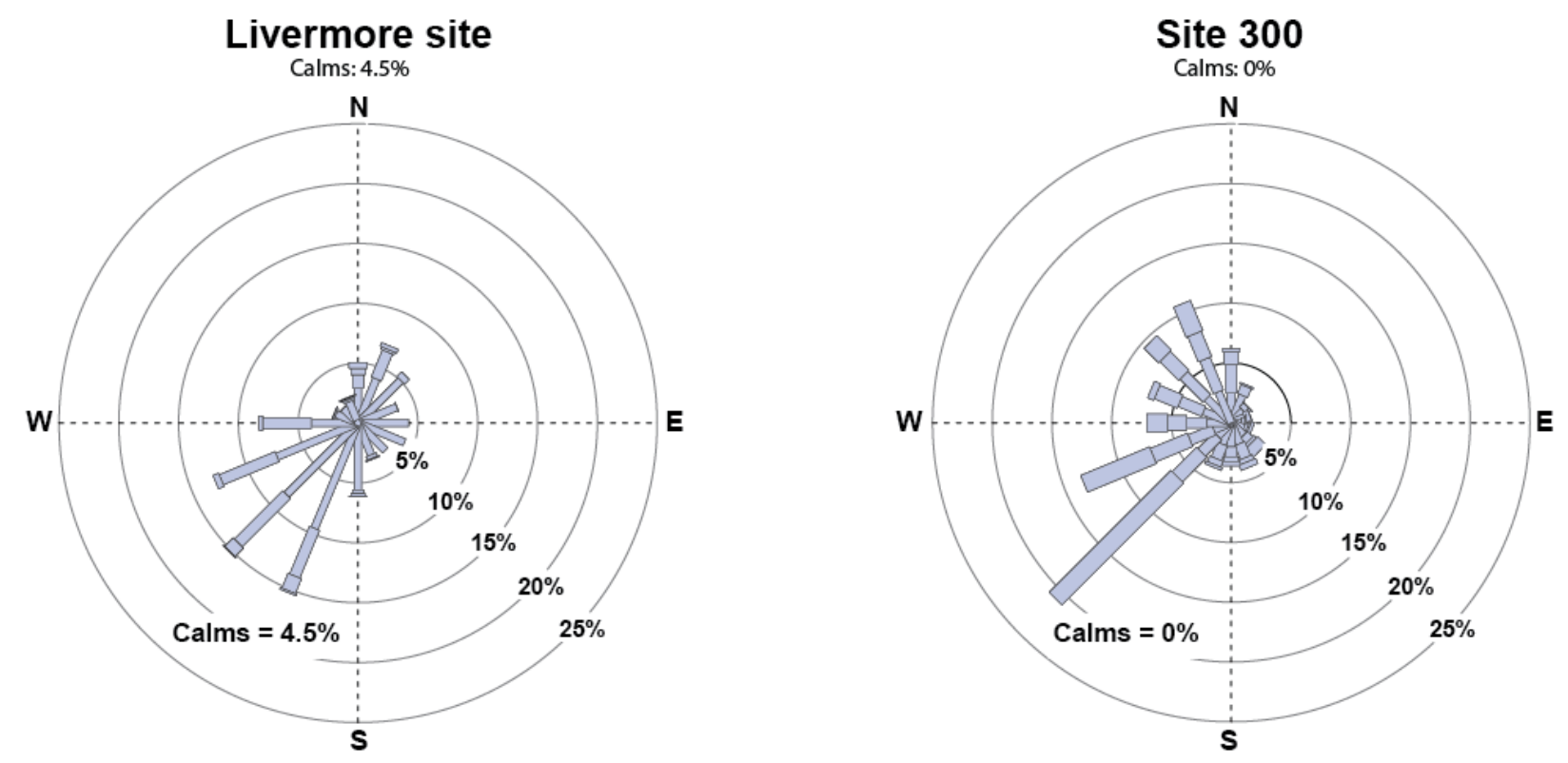

Wind speed

\begin{tabular}{ccccc} 
Calms & $0.5-2.9$ & $3.0-4.9$ & $5.0-6.9$ & $>7.0(\mathrm{~m} / \mathrm{s})$ \\
\hline Calms & $1.1-6.6$ & $6.7-11.1$ & $11.2-15.5$ & $>15.6(\mathrm{mph})$
\end{tabular}

Figure 2. Wind roses for the Livermore site and Site 300 for 2011. 
The 2011 annual wind data for both sites are displayed as wind roses in Figure 2. In the wind rose, the length of each spoke is proportional to the frequency at which the wind blows from the indicated direction; different line widths of each spoke represent wind speed classes. These data show that for the Livermore site, winds blew from the south-southwest through west-southwest about $43 \%$ of the time; for Site 300 , the data show that the winds blew from the southwest to the west-southwest about $34 \%$ of the time. The average wind speed in 2011 at the Livermore site was $2.3 \mathrm{~m} / \mathrm{s}(5.2 \mathrm{mph})$, and the average wind speed at Site 300 was $5.6 \mathrm{~m} / \mathrm{s}(12.5 \mathrm{mph})$. In 2011, the Livermore site received $25.2 \mathrm{~cm}$ of rain and Site 300 received $23.1 \mathrm{~cm}$.

\subsection{SOURCE DESCRIPTION}

Many different radioisotopes were available for use at LLNL in 2011 for research purposes, including biomedical tracers, tritium, mixed fission products, transuranic isotopes, and others-see Table 1. Radioisotope handling procedures and work enclosures are determined for each project or activity, depending on the isotopes, the quantities being used, and the types of operations being performed. Work enclosures include glove boxes, exhaust hoods, and laboratory bench tops. Exhaust paths to the atmosphere include High Efficiency Particulate Air (HEPA) filtered ventilation systems, roof vents and stacks lacking abatement devices, direct open-air dispersal of depleted uranium during explosives testing at Site 300 , and releases to ambient air from a variety of diffuse sources. Table 2 identifies the buildings, by managing organization, at LLNL where there was a potential for release of radioactive materials to the air in 2011 .

Table 1. Radionuclides used at LLNL during 2011.

\begin{tabular}{llllll}
\hline Ac-227 & Cl-36 & Ho-166m & Np-237 & Ra-226 & Th-229 \\
Ag-110m & Cm-242 & I-125 & Np-239 & Ra-228 & Th-230 \\
Am-241 & Cm-243 & I-129 & P-32 & Re-187 & Th-232 \\
Am-242m & Cm-246 & I-131 & P-33 & Rh-105 & Tl-204 \\
Am-243 & Cm-248 & Ir-192 & Pa-231 & Ru-103 & U-232 \\
Ba-133 & Co-57 & K-40 & Pb-210 & Ru-106 & U-234 \\
Ba-140 & Co-58 & Kr-85 & Pm-147 & S-35 & U-235 \\
Be-10 & Co-60 & La-140 & Pm-149 & Sb-125 & U-236 \\
Be-7 & Cs-134 & Lu-177m & Po-208 & Se-75 & U-237 \\
Bi-207 & Cs-135 & Mn-54 & Po-209 & Sr-85 & U-238 \\
C-14 & Cs-137 & Mo-99 & Po-210 & Sr-89 & Xe-133 \\
Ca-41 & Eu-152 & Na-22 & Pr-143 & Sr-90 & Xe-135 \\
Ca-45 & Eu-154 & Nb-95 & Pu-236 & Ta-177 & Y-88 \\
Cd-109 & Eu-155 & Nd-147 & Pu-238 & Tb-160 & Y-90 \\
Ce-143 & Fe-55 & Ni-56 & Pu-239 & Tc-99 & Zn-65 \\
Ce-144 & Fe-60 & Ni-63 & Pu-240 & Tc-99m & Zr-89 \\
Cf-249 & Gd-148 & Ni-66 & Pu-241 & Te-131m & Zr-95 \\
Cf-250 & Gd-153 & Np-236 & Pu-242 & Te-132 & Zr-97 \\
Cf-252 & H-3 & Np-236s & Pu-244 & Th-228 & \\
\hline
\end{tabular}


Table 2. Buildings at LLNL, by managing organization, where there is a potential for the release of radioactive materials to the air.

\begin{tabular}{|c|c|c|c|c|c|}
\hline $\begin{array}{l}\text { Director's } \\
\text { Office }\end{array}$ & $\begin{array}{l}\text { Physical \& } \\
\text { Life Sciences }\end{array}$ & Engineering & $\begin{array}{c}\text { Weapons \& } \\
\text { Complex } \\
\text { Integration }\end{array}$ & $\begin{array}{l}\text { National } \\
\text { Ignition Facility } \\
\text { \& Photon } \\
\text { Science }\end{array}$ & $\begin{array}{c}\text { Operations \& } \\
\text { Business }\end{array}$ \\
\hline $\begin{array}{l}\mathrm{B} 253 \\
\mathrm{~B} 254 \\
\mathrm{~B} 255\end{array}$ & $\begin{array}{l}\text { B132 } \\
\text { B151 } \\
\text { B194 } \\
\text { B235 } \\
\text { B282 } \\
\text { B292 } \\
\text { B341 } \\
\text { B361 } \\
\text { B364 } \\
\text { B378 }\end{array}$ & $\begin{array}{l}\text { B131 } \\
\text { B231 } \\
\text { B321 } \\
\text { B322 } \\
\text { B327 }\end{array}$ & $\begin{array}{c}\text { B331 }^{\mathrm{b}} \\
\text { B332 }^{\mathrm{b}} \\
\text { B612 } \\
\text { B625 } \\
\text { B695/696 } \\
\text { B697 }^{\mathrm{b}} \\
\text { B801 } \\
\text { B804 } \\
\text { B810A } \\
\text { B810B } \\
\text { B851 } \\
\text { B883 }\end{array}$ & $\begin{array}{l}\text { B162 } \\
\text { B298 } \\
\text { B381 } \\
\text { B391 } \\
\text { B581 } \\
\text { B582 } \\
\text { B491 }\end{array}$ & $\begin{array}{l}\text { B419 } \\
\text { B597 }\end{array}$ \\
\hline
\end{tabular}

a B132 is managed by Global Security.

b Continuous monitoring occurs at one or more exhaust points at the building. 
LLNL places radionuclide emission sources into one of two categories; major sources or minor sources. Major sources are defined as those that have the potential to emit radionuclides that could result in an annual potential dose of 0.1 mrem $(1 \mu \mathrm{Sv})$ or more to a member of the public at an off-site location; the radionuclide NESHAPs regulation requires continuous monitoring where the annual potential dose is in excess of 0.1 mrem $(1 \mu \mathrm{Sv})$. Minor sources are defined as sources that do not have the potential to cause an annual dose of $0.1 \mathrm{mrem}(1 \mu \mathrm{Sv})$. At LLNL, all major sources of emissions are point sources, i.e., stack emission points; however, minor sources include both point sources and diffuse sources.

\subsection{MAJOR SOURCES: MEASURED EMISSIONS}

In 2011, there were six facilities at the Livermore site and one facility at Site 300 that had radionuclide air effluent monitoring systems. These facilities are listed in Table 3, along with the number of samplers, the types of samplers, and the analytes of interest. Some of these facilities have the potential to emit radionuclides that would cause an annual dose in excess of the $0.1 \mathrm{mrem}(1 \mu \mathrm{Sv})$ standard; these sources are major sources following the definition given above. Others of these facilities have in the past had emissions required monitoring, and the monitoring has been maintained to assure that the emissions continue to be well characterized and that the potential effect on the public and the environment is well understood.

Many of the monitored stacks at LLNL have effluent controls, such as HEPA filters, to collect materials before they are emitted to the atmosphere. Air samples for particulate emissions are extracted downstream of HEPA filters and prior to the discharge point to the atmosphere. Particles are collected on cellulose membrane filters. The sample filters are removed and analyzed for radioactive particulate activity on a weekly or biweekly frequency depending on the facility. In all cases, continuous passive filter aerosol collection systems are used. At some facilities, continuous air monitors (CAMs) also sample the stack air exhaust for radionuclides. CAMs have an alarm capability for the facility in the event of an unplanned release of alpha activity. CAMs are used for facility personnel safety; they are not used for NESHAPs compliance demonstration. 
Table 3. Air effluent sampling systems and locations.

\begin{tabular}{|c|c|c|c|c|}
\hline Building & Facility & Analytes & Sample type & $\begin{array}{c}\text { Number of } \\
\text { samplers }\end{array}$ \\
\hline 235 & $\begin{array}{l}\text { Building in Physical and Life } \\
\text { Sciences Directorate }\end{array}$ & Gross $\alpha, \beta$ on particles & Filter & 1 \\
\hline \multirow[t]{2}{*}{331} & Tritium Facility & $\begin{array}{l}\text { Gaseous tritium/ tritiated } \\
\text { water vapor }\end{array}$ & Ionization Chamber $^{a}$ & 4 \\
\hline & & $\begin{array}{l}\text { Gaseous tritium/ tritiated } \\
\text { water vapor }\end{array}$ & Glycol Bubblers & 2 \\
\hline \multirow[t]{2}{*}{332} & Plutonium Facility & Gross $\alpha, \beta$ on particles & Filters & 15 \\
\hline & & Gross $\alpha, \beta$ on particles & $\mathrm{CAM}^{\mathrm{a}}$ & 12 \\
\hline 491 & Isotope Separation $^{b}$ & Gross $\alpha, \beta$ on particles & Filter & 1 \\
\hline \multirow[t]{4}{*}{581} & National Ignition Facility & $\begin{array}{l}\text { Gross } \alpha, \beta, \text { Gamma suite } \\
\text { on particles }\end{array}$ & Filter & 1 \\
\hline & & Radioiodine (volatile) & TEDA cartridge & 1 \\
\hline & & $\begin{array}{l}\text { Gaseous tritium/ tritiated } \\
\text { water vapor }\end{array}$ & Glycol Bubbler & 1 \\
\hline & & $\begin{array}{l}\text { Gaseous tritium/ tritiated } \\
\text { water vapor }\end{array}$ & Ionization Chamber ${ }^{\mathrm{a}}$ & 1 \\
\hline \multirow[t]{2}{*}{$695 / 696$} & $\begin{array}{l}\text { Decontamination and Waste } \\
\text { Treatment Facility }\end{array}$ & Gross $\alpha, \beta$ on particles & Filter & 1 \\
\hline & & $\begin{array}{l}\text { Gaseous tritium/ tritiated } \\
\text { water vapor }\end{array}$ & Glycol Bubbler & 1 \\
\hline $801 \mathrm{~A}$ & $\begin{array}{l}\text { Contained Firing Facility (Site } \\
300)\end{array}$ & Gross $\alpha, \beta$ on particles & Filter & 1 \\
\hline
\end{tabular}

Note: "CAM" denotes continuous air monitors.

a Alarmed systems used for notification only so that any unplanned release may be detected and mitigated; they are not used for NESHAPs compliance demonstration.

b Isotope separation operations are discontinued; area now used for storage of contaminated parts.

Detection of radioactive particulate activity resulting from particles collected on the air filters is accomplished using gas flow proportional counters and gamma spectroscopy. For verification of the operation of the counting system, calibration sources, and background samples, are interspersed among with the sample filters for analysis. The Radiological Measurements Laboratory (RML) in LLNL's Radiation Protection Functional Area and the Environmental Monitoring Radio-analytical Laboratory (EMRL) in the Physical and Life Sciences Directorate perform the analyses.

When the result for gross alpha or gross beta on a particulate sample is greater than the minimum detectable concentration (MDC) for gross alpha activity, the filter is recounted. If the second result is also above the MDC, the filter is submitted to the EMRL for isotopic analysis to determine whether the activity on the filter is the result of naturally occurring radionuclides or is reportable as a radionuclide emission from the facility. 
Glycol bubblers are used to monitor for tritium releases from the Decontamination Waste Treatment Facility (DWTF) stack, the two Tritium Facility (Building 331) stacks, and the National Ignition Facility (NIF) stack. In addition to this NESHAPs compliance monitoring, the two Tritium Facility stacks, and the NIF stack are monitored using ion chambers. The ion chamber monitors are set to alarm at designated tritium concentrations to identify accidental or off-normal releases. Ion chambers are in place for notification only so that any unplanned release may be detected and mitigated; they are not used for NESHAPs compliance demonstration. All of the stack samplers monitor continuously.

Because tritium can be released in the form of either tritiated water vapor (HTO) or gaseous tritium (HT), glycol bubblers employ a two-stage glycol impinging process to capture each physical form. Stack air to be sampled enters the instrument and flows through the first stage impingers, capturing the HTO present. Next, the sampled air is directed through a heated palladium catalyst where oxidation of any HT in the sample takes place, converting gaseous tritium to HTO, which is then collected in the second stage impingers. The impingers are analyzed by the RML using liquid scintillation analysis. This type of sampling quantifies the amount of tritium for both species, HT and HTO.

Triethylenediamine (TEDA) cartridges are used to sample for radioactive iodines in gaseous or vapor state. The TEDA is impregnated into carbon (activated carbon) by the manufacturer and is housed in a plastic cartridge of standard industry size $21 / 4 "$ diameter by 1 " thick (30 x 50 Mesh). Stack air is directed through the TEDA cartridge that is located post a particulate filter (two-stage filter housing). Both the particulate filter and the TEDA cartridge are counted by gamma spectroscopy by the EMRL.

In 2011, a total of $188.6 \mathrm{Ci}(6978 \mathrm{GBq})$ of measured tritium was released from the Tritium Facility. Of this, approximately $32 \%$ of tritium was released as vapor (HTO). The remaining $68 \%$ released was gaseous tritium $(\mathrm{HT})$.

In 2011, $0.015 \mathrm{Ci}(0.56 \mathrm{GBq})$ of measured tritium was released from the DWTF stack exhaust. The tritium released was approximately $75 \%$ vapor (HTO) and $25 \%$ gaseous tritium (HT).

The National Ignition Facility (NIF) released a total of $1.22 \mathrm{Ci}(45.1 \mathrm{GBq})$ of measured tritium from the stack exhaust in 2011. A total of $0.836 \mathrm{Ci}(30.9 \mathrm{GBq})$ was released as vapor (HTO), $0.385 \mathrm{Ci}(14.2 \mathrm{GBq})$ as gaseous $(\mathrm{HT})$, and $1.4 \times 10^{-4} \mathrm{Ci}\left(5.2 \times 10^{-3} \mathrm{GBq}\right)$ of tritiated particulate.

The Contained Firing Facility at Site 300 had measured depleted uranium emissions in 2011. A total of $5.6 \times 10^{-9} \mathrm{Ci}\left(2.1 \times 10^{-7} \mathrm{GBq}\right)$ of uranium-234, $4.1 \times 10^{-10} \mathrm{Ci}(1.5 \times$ $\left.10^{-8} \mathrm{GBq}\right)$ of uranium-235, and $3.2 \times 10^{-8} \mathrm{Ci}\left(1.2 \times 10^{-6} \mathrm{GBq}\right)$ of uranium-238 was released in particulate form.

None of the other facilities monitored for radionuclides had reportable emissions in 2011. 


\subsection{MINOR SOURCES: AMBIENT MEASUREMENT COMPARISON}

With EPA's Region IX approval, LLNL demonstrates compliance for minor emissions sources (both non-monitored stack and area sources) through the use of ambient air monitoring data. The method entails comparing measured ambient air concentrations at the location of the site-wide maximally exposed individual (SW-MEI) to concentration limits set by EPA in its Table 2 of Appendix E to 40 CFR 61. The radionuclides for which the comparisons are made are tritium and plutonium 239+240 for the Livermore SW-MEI and uranium-238 for the Site 300 SW-MEI (see Table 6 in section 3.3.2).

\subsection{MINOR SOURCES: SOURCE TERM ESTIMATE}

In order to take into account the dose contributions from diffuse minor sources, LLNL estimated the source terms for these sources using a mathematical optimization routine that minimizes the root-mean-square $(\mathrm{rm})$ differences between modeled and measured average annual ambient tritium concentrations (see Figure 5 in Section 3.3.2 for the ambient air sampling locations). This process has two parts.

First, CAP88-PC is used to model the contribution each source (both point and diffuse) makes to the annual average tritiated water vapor (HTO) concentration at each of the ambient air monitoring locations. Each point source is modeled using source-specific model parameters (activity, stack height, etc.). The diffuse sources are modeled using a unit source $(1 \mathrm{Ci})$, a 1-meter height, a 10-meter diameter, and a fixed plume rise across stability classes A through F. All models use the same LLNL 2011 wind file. The individual contributions (both point and diffuse) at each monitoring location are added to produce an all-sources-combined model estimate of the annual average ambient concentration at each location.

Second, the $1 \mathrm{Ci}$ source term for each diffuse source is adjusted independently using a mathematical search optimization routine. The point sources are held fixed. The adjusted diffuse source terms that give the best fit of the all-sources-combined model concentrations to the measured concentrations are then used to calculate the dose contribution from each diffuse source.

In 2011, the best-fit diffuse source term estimates are $1.7 \mathrm{Ci}$ for the Building 331 Waste Accumulation Area (WAA), $1.3 \mathrm{Ci}$ for the Building $612 \mathrm{Yard}$, and $6.1 \mathrm{Ci}$ for the Building 695/696 Yard. These estimates are consistent with the reported activities and contents of those areas. The measured and best-fit model annual average results are shown in Figure 3. 


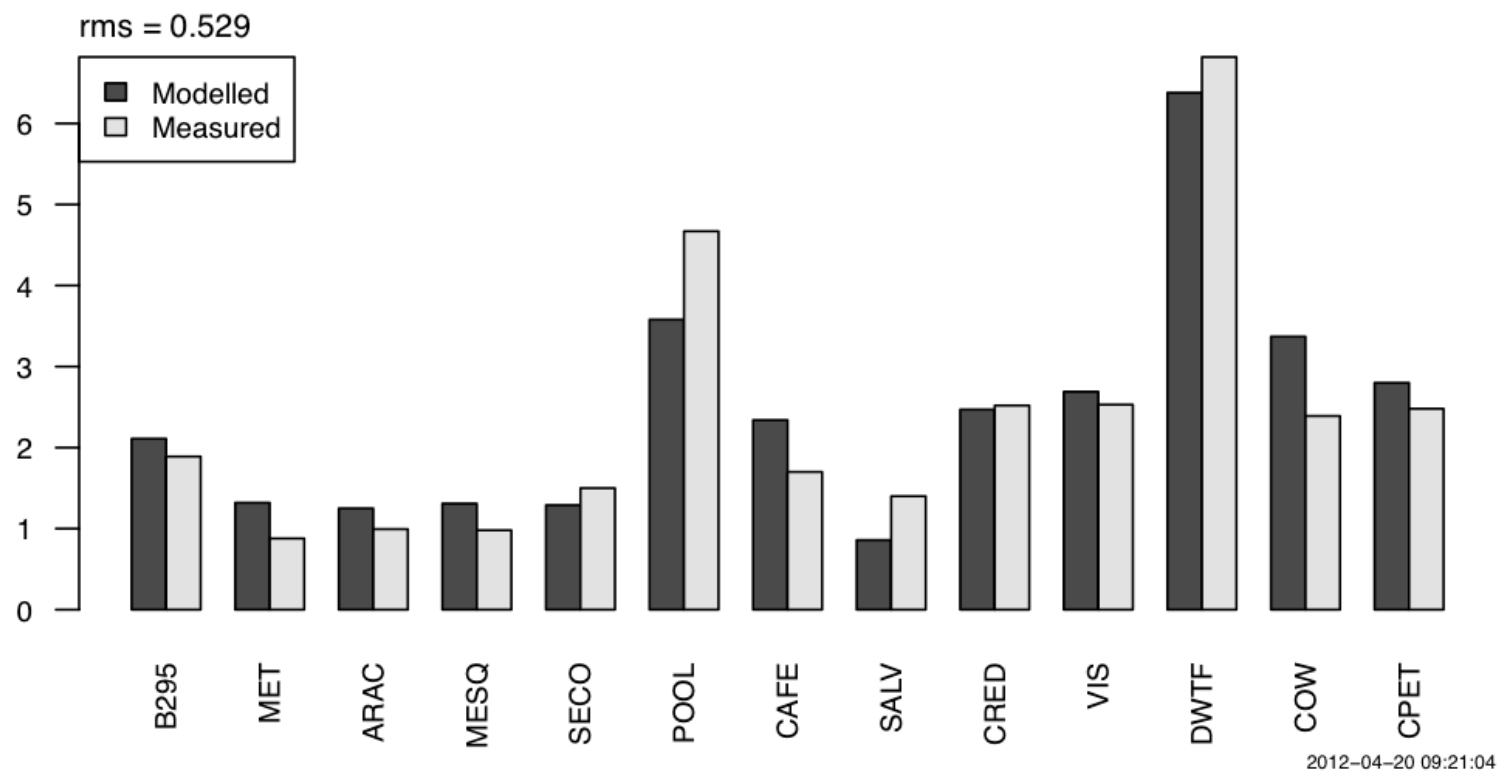

Figure 3. Comparison of measured and modeled annual average concentrations of tritiated water vapor (HTO) in units of $\mathrm{pCi} / \mathrm{m}^{3}$ in air at Livermore site ambient air locations, 2011.

\subsection{MINOR SOURCES: OPEN-AIR TESTS}

Another potential source of radioactive air emissions from LLNL operations at Site 300 is the emission of materials from open-air explosives tests. In 2011, there were no open-air explosives tests that contained radioactive materials. 


\section{Dose Assessment}

\subsection{GENERAL}

To comply with NESHAPs regulations and DOE guidance, the EPA-approved atmospheric dispersion and radiation dose calculation computer code, CAP88-PC, Version 1.0, was used to calculate the dose at various distances and from various release points. For diffuse sources having a significant contribution to total dose, in addition to comparing the emissions to the concentration limits set by EPA in its Table 2 of Appendix E to 40 CFR 61, doses were calculated using either CAP88-PC or standard breathing rates and dose conversion factors.

For LLNL to comply with the NESHAPs regulations, the LLNL SW-MEI cannot receive an effective dose equivalent greater than $10 \mathrm{mrem} / \mathrm{y}(100 \mu \mathrm{Sv} / \mathrm{y})$. The SW-MEI is defined as the hypothetical member of the public at a single residence, school, business, church, or other such facility who receives the greatest LLNL induced dose from the combination of all evaluated radionuclide source emissions, as determined by modeling. At the Livermore site, the SW-MEI for 2011 was located at the UNCLE Credit Union, about 30 feet $(10 \mathrm{~m})$ outside the controlled eastern fence line of the site, but about 30 feet $(10 \mathrm{~m})$ within the perimeter of the site property. At Site 300, the 2011 SW-MEI was located at the boundary with the Carnegie State Vehicle Recreation Area, managed by the California Department of Parks and Recreation, approximately 1.9 miles $(3.2 \mathrm{~km})$ south-southeast of the firing table at Building 851 . The locations of the SW-MEls for both LLNL sites are shown in Figure 4.
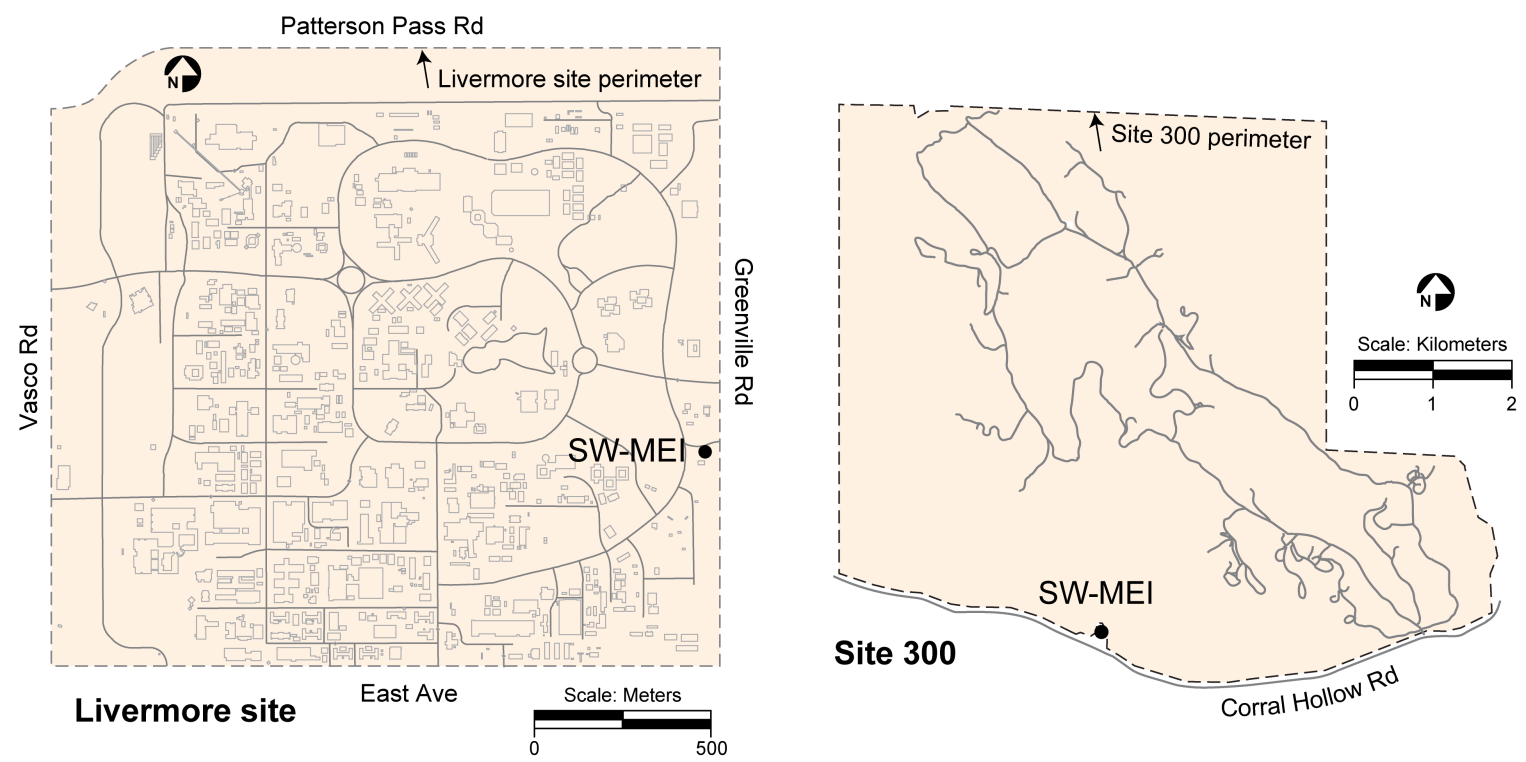

Figure 4. Location of Site-Wide Maximally Exposed Individual (SW-MEI) at the Livermore site and Site 300, 2011. 


\subsection{CAP88-PC INPUT PARAMETERS}

Input parameters to CAP88-PC include the emissions discussed in Section 2, and building-specific and common parameters, discussed below. To estimate dose, CAP88-PC, Version 1, provides a library of 265 radionuclides. In addition, when calculating dose from particulate alpha- and beta-emitting radionuclides, LLNL assigns gross alpha and gross beta measurements to the radionuclides handled in the facility, when they can be specifically identified, or to plutonium-239+240 and strontium-90, respectively. The use of plutonium-239+240 and strontium-90 to represent alpha and beta emissions provides a health-conservative estimate of the dose.

\subsubsection{Building-Specific Parameters}

For dose assessment, LLNL uses building-specific information about radionuclide releases, as well as building-specific parameters for stack height, stack exhaust rate, stack diameter, and distances to the fence line. The building specific parameters are presented in Attachment 1.

\subsubsection{Common Parameters}

The input parameters that are common among LLNL sources are the agricultural parameters. Meteorological data from the LLNL Livermore site meteorological tower are used to model Livermore site sources, and meteorological data from the LLNL Site 300 meteorological tower are used to model Site 300 sources. Site-specific values for annual precipitation $(9.9 \mathrm{in}$. [25.2 cm] for the Livermore site and $9.1 \mathrm{in}$. [23.1 cm] for Site 300) and annual average ambient temperature $\left(56.8^{\circ} \mathrm{F}\left[13.8^{\circ} \mathrm{C}\right]\right.$ for the Livermore site and $60.1^{\circ} \mathrm{F}\left[15.6^{\circ} \mathrm{C}\right]$ for Site 300 ) were used. The CAP88-PC, Version 1, default for absolute humidity, $8 \mathrm{~g} / \mathrm{m} 3$, is reasonably representative of conditions at LLNL, was used. The value for lid (mixing) height of 2,460 ft $(750 \mathrm{~m})$ was chosen for the Livermore site, whereas the lid height value for Site 300 was $3,280 \mathrm{ft}(1,000 \mathrm{~m})$. The 2011 wind data are provided in Attachment 2.

For agricultural parameters in CAP88-PC, LLNL used mean values for California based on data from the U.S. Department of Agriculture (USDA 2007). The mean values are shown in Table 4.

Table 4. Agricultural parameter values representing LLNL used in CAP88-PC.

\begin{tabular}{ll}
\hline Parameter & Value \\
\hline Beef cattle density (\# cows $/ \mathrm{km}^{2}$ ) & 4.8 \\
Milk cattle density (\# cows $/ \mathrm{km}^{2}$ ) & 0.025 \\
Land fraction cultivated for vegetable crops & 0.065 \\
\hline
\end{tabular}

For individual and collective doses from ingestion, it was assumed that $100 \%$ of milk is imported (i.e., free from LLNL-generated radioactivity), and that vegetables and meat are $25 \%$ home-grown and $75 \%$ imported. 


\subsection{COMPLIANCE ASSESSMENT}

\subsubsection{Major Sources}

Doses from LLNL's major sources, which are point sources for which monitoring is required, were evaluated using CAP88-PC and the input parameters discussed above. The modeled doses to the SW-MEI for the facilities where there were measurements greater than the minimum detectable concentration (MDC) are shown in Table 5. The specific results for all sources are provided in Attachment 1.

Table 5. Point source doses for 2011.

\begin{tabular}{lc}
\hline Facility & Dose (mrem) \\
\hline Tritium Facility (B331) & $1.5 \times 10^{-2}$ \\
NIF (B581) & $2.8 \times 10^{-5}$ \\
DWTF (B695/696) & $5.8 \times 10^{-7}$ \\
CFF (B801A) & $9.0 \times 10^{-8}$ \\
\hline
\end{tabular}

\subsubsection{Minor Sources}

LLNL has many minor sources; most of them are point sources and a few are diffuse. As stated previously, with EPA's Region IX approval, LLNL demonstrates compliance for minor emissions sources (both diffuse and non-monitored stack sources) through the comparison of ambient air monitoring data with concentration limits set by EPA in Table 2 of Appendix E to 40 CFR 61. This is done for tritium and plutonium-239+240 for the Livermore SW-MEI and uranium-238 for the Site 300 SW-MEI. The 2011 average monitoring results for tritium and plutonium from the sampling location in closest proximity to the Livermore site SW-MEI (UNCLE Credit Union [CRED]) were used to represent the SW-MEI for the purposes of this minor source comparison. (See Figure $\mathbf{5}$ for a map of all Livermore site sampling locations).

The results of these comparisons are shown in Table 6. Only one of twelve 2011 monthly measurements for plutonium-239+240 at CRED was considered to be a detection. The conservative approach was taken using monthly measurements at CRED with an estimated activity greater than zero in the average (seven of twelve monthly measurements total). At Site 300, wind-driven resuspension of soil contaminated with depleted uranium is of greatest interest in the minor source category. Since 2008, but in contrast to prior years, no ambient measurements for uranium showed a contribution from depleted uranium - the uranium-238 value in Table 6 represents a natural background value (see footnote $\mathrm{c}$ ). The lack of measurements indicating the presence of depleted uranium may also be related to the fact that no outdoor explosives tests that included depleted uranium were conducted in 2011. Because there was no source term for depleted uranium resuspension at Site 300 , there is no minor source contribution to the calculated dose for 2011 at the SW-MEI. 


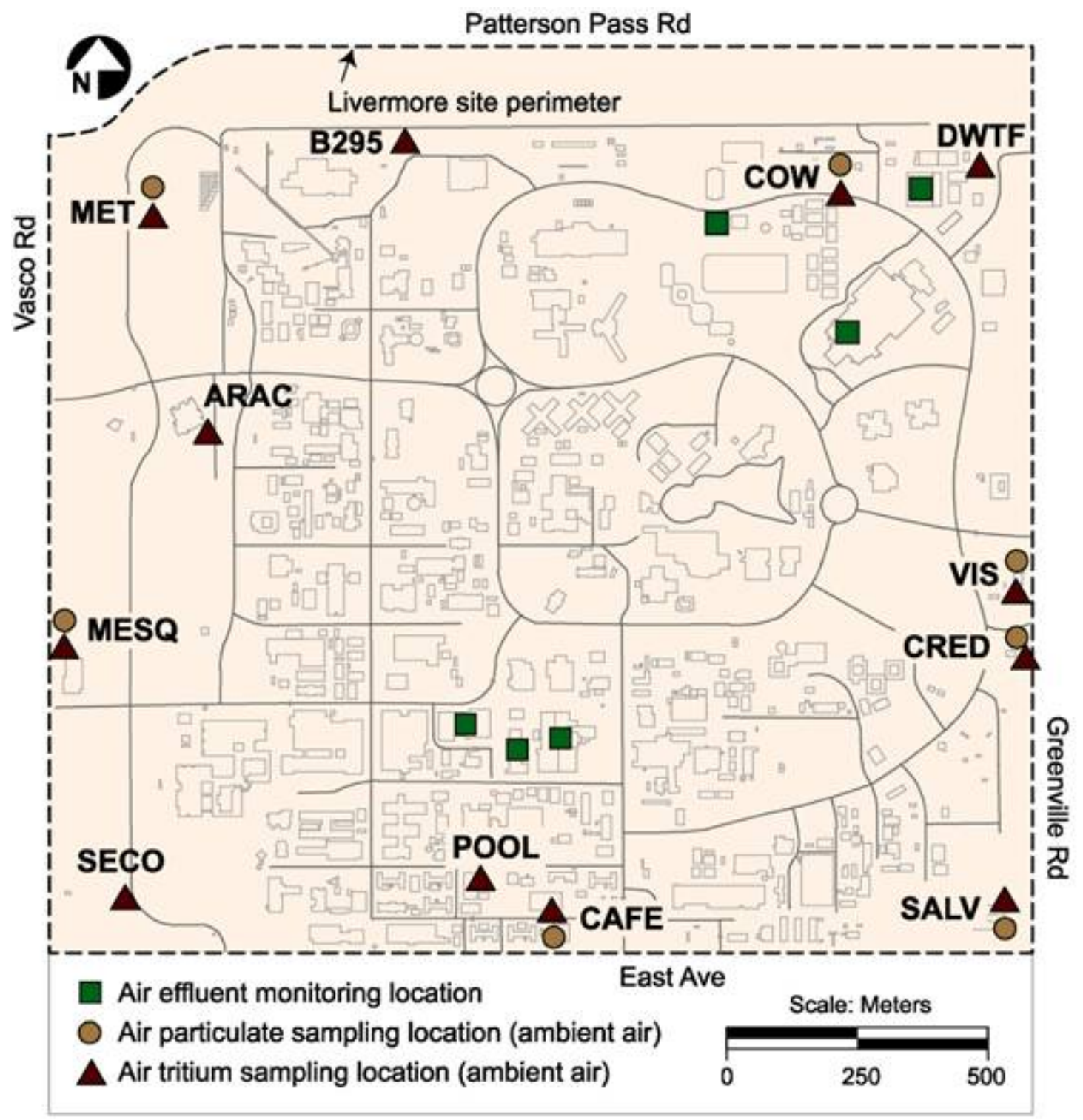

Figure 5. Radiological air monitoring locations at the Livermore

The measured concentrations at the SW-MEI are presented in Table 6. Also shown in Table 6 are EPA's standards from Table 2 of Appendix E to 40 CFR 61. As demonstrated by the calculation of the fraction of the standard, LLNL's measured concentrations in air for tritium, plutonium-239+240, and uranium-238 are a fraction 0.004 $(0.4 \%)$ or less of the standard for these radionuclides 
Table 6. Mean concentrations of radionuclides of concern at the location of the SW-MEI in 2011 compared to EPA's concentration standard.

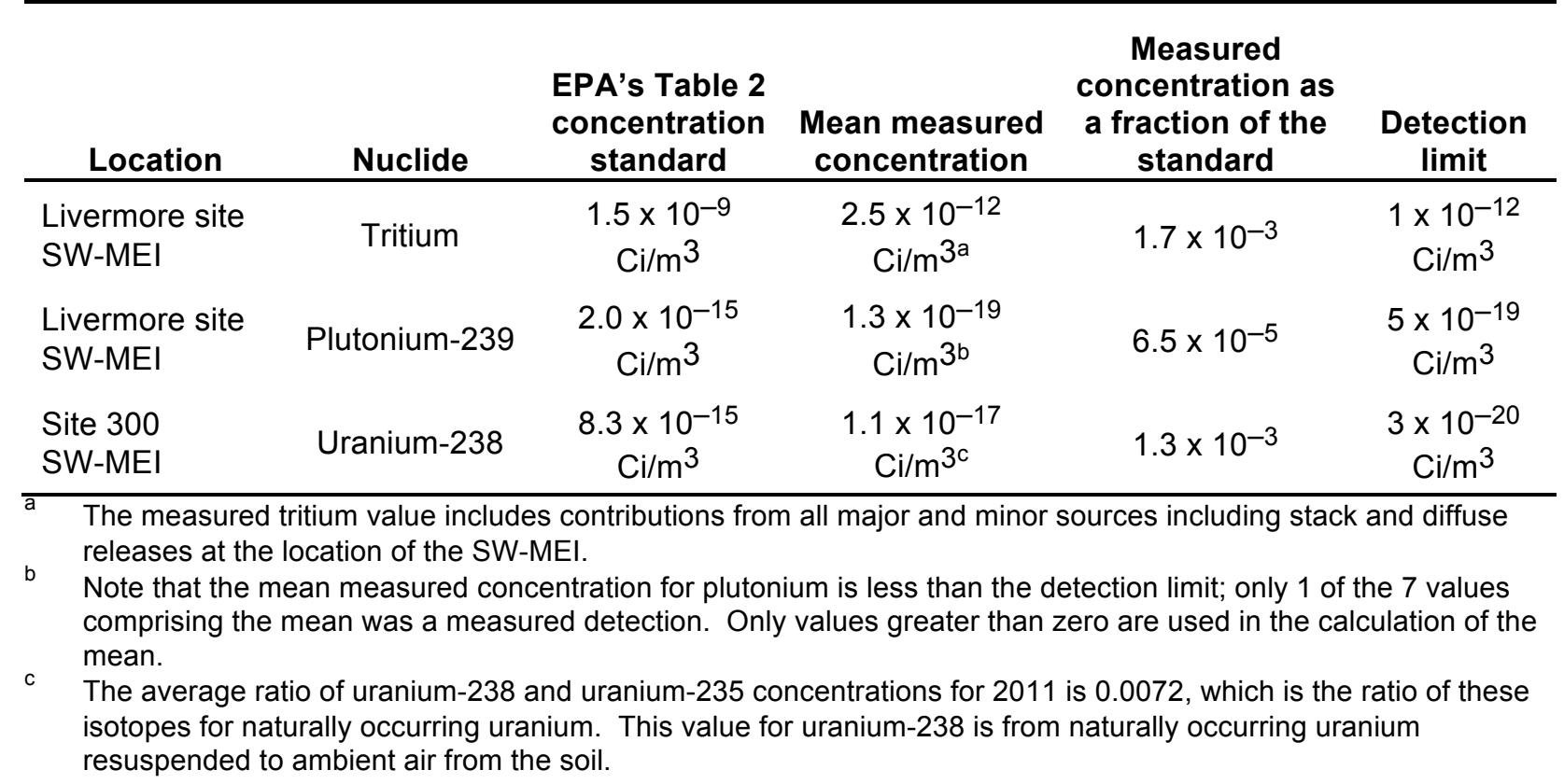

The source term for diffuse sources of tritium was developed using a mathematical model (section 2.3) and the doses were calculated using CAP88-PC (attachment 1 lists the specific doses from diffuse sources). The Southeast Quadrant of the Livermore site mean annual concentration of Pu-239 for all results greater than zero was $1.3 \times 10^{-19} \mathrm{Ci} / \mathrm{m}^{3}$ $\left(4.7 \times 10^{-9} \mathrm{~Bq} / \mathrm{m}^{3}\right)$. Using the dose conversion factor of $3.08 \times 10^{5} \mathrm{mrem} / \mu \mathrm{Ci}\left(8.32 \times 10^{-5}\right.$ Sv/Bq) from Federal Guidance Report No. 11, EPA-520/1-88-020, U.S. Environmental Protection Agency (1988) for Pu-239, and the reference man breathing rate of $8400 \mathrm{~m}^{3} / \mathrm{y}$ (International Commission on Radiological Protection [ICRP], 1975, Reference Man: Anatomical Physiological and Metabolic Characteristics. Oxford: Pergamon Press; ICRP Publication 23), the dose was determined to be $3.3 \times 10^{-4} \mathrm{mrem}\left(3.3 \times 10^{-3} \mu \mathrm{Sv}\right)$ for 2011. The total diffuse source dose for 2011 was $1.9 \times 10^{-3} \mathrm{mrem}\left(1.9 \times 10^{-2} \mu \mathrm{Sv}\right)$ for the Livermore site; because there was no diffuse source term for Site 300 , no minor source diffuse dose was calculated.

\subsubsection{MEI Dose}

Doses from LLNL's airborne emissions are well below the 10 mrem (100 $\mu$ Sv) NESHAPs annual dose standard. The annual doses to the hypothetical SW-MEI at the Livermore site and at Site 300 are:

- Livermore site: 0.017 mrem $(0.17 \mu \mathrm{Sv})$

- Site 300: $9.0 \times 10^{-8} \mathrm{mrem}\left(9.0 \times 10^{-7} \mu \mathrm{Sv}\right)$

The EPA-approved software calculates the dose assuming a person resides there all year for 24 hours a day, eats meat and vegetables grown at the location (see agricultural parameters in section 3.2.2), and drinks contaminated water. Thus, the calculated dose to this hypothetical person, the SW-MEI, is greater than the dose to an actual resident. 
Table 7 presents 2011 doses with those of previous years. Diffuse source doses were not reported for the Livermore site for 1990 and 1991, and were not reported for Site 300 for 1990 through 1992. 
Table 7. Doses (in mrem) calculated for the Site-Wide Maximally Exposed Individual (SW-MEI) for the Livermore site and Site 300, 1990 to 2011.

\begin{tabular}{|c|c|c|c|}
\hline Year & Total Dose & Point Source Dose & Diffuse Source Dose \\
\hline $\begin{array}{c}\text { Livermore site } \\
2011\end{array}$ & 0.017 & $0.015^{\mathrm{a}}$ & 0.0019 \\
\hline 2010 & 0.011 & $0.0033^{\mathrm{a}}$ & 0.0074 \\
\hline 2009 & $0.0042^{\mathrm{a}}$ & $0.0015^{\mathrm{a}}$ & 0.0027 \\
\hline 2008 & $0.0013^{a}$ & $0.00033^{a}$ & 0.00095 \\
\hline 2007 & $0.0031^{\mathrm{a}}$ & $0.0013^{a}$ & 0.0018 \\
\hline 2006 & $0.0045^{\mathrm{a}}$ & $0.0016^{a}$ & 0.0029 \\
\hline 2005 & $0.0065^{\mathrm{a}}$ & $0.0027^{a}$ & 0.0038 \\
\hline 2004 & $0.0079^{a}$ & $0.0021^{\mathrm{a}}$ & 0.0058 \\
\hline 2003 & $0.044^{\mathrm{a}}$ & $0.024^{\mathrm{a}}$ & 0.020 \\
\hline 2002 & $0.023^{\mathrm{a}}$ & $0.010^{\mathrm{a}}$ & 0.013 \\
\hline 2001 & $0.017^{\mathrm{a}}$ & $0.0057^{\mathrm{a}}$ & 0.011 \\
\hline 2000 & $0.038^{a}$ & $0.017^{\mathrm{a}}$ & 0.021 \\
\hline 1999 & $0.12^{\mathrm{a}}$ & $0.094^{\mathrm{a}}$ & 0.028 \\
\hline 1998 & $0.055^{\mathrm{a}}$ & $0.031^{\mathrm{a}}$ & 0.024 \\
\hline 1997 & 0.097 & 0.078 & 0.019 \\
\hline 1996 & 0.093 & 0.048 & 0.045 \\
\hline 1995 & 0.041 & 0.019 & 0.022 \\
\hline 1994 & 0.065 & 0.042 & 0.023 \\
\hline 1993 & 0.066 & 0.040 & 0.026 \\
\hline 1992 & 0.079 & 0.069 & 0.010 \\
\hline 1991 & 0.234 & $-^{\mathrm{b}}$ & $-^{\mathrm{b}}$ \\
\hline 1990 & 0.240 & $-^{b}$ & $-^{\mathrm{b}}$ \\
\hline \multicolumn{4}{|l|}{ Site $\mathbf{3 0 0}$} \\
\hline 2011 & $9.0 \times 10^{-8}$ & $9.0 \times 10^{-8}$ & $-^{c}$ \\
\hline 2010 & $5.7 \times 10^{-7}$ & $5.7 \times 10^{-7}$ & $-^{c}$ \\
\hline 2009 & $2.7 \times 10^{-7}$ & $2.7 \times 10^{-7}$ & $-^{c}$ \\
\hline 2008 & $4.4 \times 10^{-8}$ & $4.4 \times 10^{-8}$ & $-^{c}$ \\
\hline 2007 & 0.0035 & 0.0031 & 0.00035 \\
\hline 2006 & 0.016 & 0.014 & 0.0020 \\
\hline 2005 & 0.018 & 0.0088 & 0.0094 \\
\hline 2004 & 0.026 & 0.025 & 0.00086 \\
\hline 2003 & 0.017 & 0.017 & 0.00034 \\
\hline 2002 & 0.021 & 0.018 & 0.0033 \\
\hline 2001 & 0.054 & 0.050 & 0.0037 \\
\hline 2000 & 0.019 & 0.015 & 0.0037 \\
\hline 1999 & 0.035 & 0.034 & 0.0012 \\
\hline 1998 & 0.024 & 0.019 & 0.005 \\
\hline 1997 & 0.020 & 0.011 & 0.0088 \\
\hline 1996 & 0.033 & 0.033 & 0.00045 \\
\hline 1995 & 0.023 & 0.020 & 0.003 \\
\hline 1994 & 0.081 & 0.049 & 0.032 \\
\hline 1993 & 0.037 & 0.011 & 0.026 \\
\hline 1992 & 0.021 & 0.021 & $-^{d}$ \\
\hline 1991 & 0.044 & 0.044 & $-^{d}$ \\
\hline 1990 & 0.057 & 0.057 & $-^{d}$ \\
\hline
\end{tabular}

a The dose includes HT emissions modeled as HTO. Modeling HT emissions as such results in an overestimation of the dose. This methodology is used for purposes of compliance, as directed by EPA Region IX.

b Point and diffuse source doses were not reported separately from the total dose for the Livermore site for 1990 and 1991 .

c No diffuse emissions dose was calculated for 2008, 2009, 2010, and 2011 because ambient monitoring yielded no results indicating the presence of depleted uranium at the SW-MEI.

d No diffuse emissions were evaluated at Site 300 for years before 1993. 
I certify under penalty of law that this document and all attachments were prepared under my direction or supervision in accordance with a system designed to assure that qualified personnel properly gather and evaluate the information submitted. Based on my inquiry of the person or persons who manage the system, or those persons directly responsible for gathering the information, the information submitted is, to the best of my knowledge and belief, true, accurate, and complete. I am aware that there are significant penalties for submitting false information, including the possibility of fine and imprisonment for knowing violations.

Name: $\quad$ Frances Alston

Associate Director

Environment, Safety \& Health

Lawrence Livermore National Laboratory

7000 East Avenue, L-510

Livermore, CA 94551

Signature:

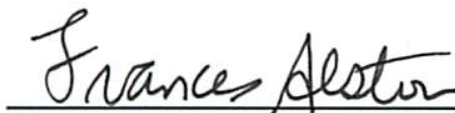

Date: $6 / 25 / 12$

Frances Alston

I certify under penalty of law that I have personally examined and am familiar with the information submitted herein, and based on my inquiry of those individuals immediately responsible for obtaining the information, I believe that the submitted information is true, accurate, and complete. I am aware that there are significant penalties for submitting false information, including the possibility of fine and imprisonment. See 18 U.S.C. 1001.

Name: $\quad$ Heather Larson

Assistant Manager for Environment, Safety \& Health

U.S. Department of Energy

National Nuclear Security Administration

Livermore Site Office

7000 East Avenue, L-293

Livermore, CA 94551

Signature: Heatlen larion

Date: $6 / 28 / 12$

Heather Larson 


\section{5 Additional Information}

\subsection{UNPLANNED RELEASES}

There were no unplanned releases from the Livermore site or Site 300 in 2011. 


\section{6 Supplemental Information}

\subsection{COLLECTIVE DOSE ASSESSMENT}

Collective population dose is calculated using CAP88-PC as the average radiation dose to a person in a specified area, multiplied by the number of people in that area. In accordance with DOE and EPA guidance documents, all radionuclides potentially emitted in 2011 were assumed to be released from a central location. The total population within 50 miles $(80 \mathrm{~km})$ of the Livermore site is approximately $7,770,000$, and the total population within 50 miles $(80 \mathrm{~km}$ ) of Site 300 is approximately $7,110,000$. The populations were derived using ORNL LANDSCAN ${ }^{\text {TM }} 2010$ data and ESRI ARCMAP software. The population file is provided in Attachment 3. The estimated collective dose attributable to LLNL airborne emissions in 2011 to persons living within 50 miles $(80 \mathrm{~km})$ of the Livermore site is 2.9 person-rem ( 0.029 person-Sv) and to persons living within 50 miles $(80 \mathrm{~km})$ of Site 300 is $2.3 \times 10^{-5}$ person-rem $\left(2.3 \times 10^{-7}\right.$ person-Sv).

\subsection{CFR 61 SUBPARTS Q AND T}

LLNL does not have storage and disposal facilities for radium containing materials that would be a significant source of radon. Emissions of radon from LLNL research experiments did not occur in 2011. LLNL does not have or store any uranium mill tailings.

\subsection{PERIODIC CONFIRMATORY MEASUREMENT}

Results of NESHAPs periodic confirmatory measurements (PCM) are intended to support or confirm two objectives: 1) that those operations not continuously monitored do not, in fact, need to be continuously monitored and 2) that radionuclide usageinventory-based estimates of emissions and their corresponding doses are conservative.

For sources evaluated to have a potential to result in a dose less than the regulatory value of $0.1 \mathrm{mrem} / \mathrm{y}$ that requires continuous monitoring under Subpart $\mathrm{H}$, LLNL achieves the PCM objectives by fulfilling the requirements stated in 40 CFR 61.93, paragraph (e) with its ambient air monitoring program. The ambient air monitoring effort includes thirty-two sampling locations with forty-six samplers placed in strategic areas (see the Air Monitoring Programs section in the LLNL Site Annual Environmental Report [https://saer.IInl.gov/] for a description of LLNL's ambient air radiological monitoring).

\subsection{FACILITY COMPLIANCE}

In 2011, LLNL maintained its compliance with 40 CFR 61 Subpart H. All emissions resulted in calculated doses well below the 10 mrem (100 $\mu$ Sv $)$ standard. The total 
estimated dose from airborne emissions from the Livermore site was $0.017 \mathrm{mrem}$ $(0.17 \mu \mathrm{Sv})$ and the total estimated dose from airborne emissions from Site 300 was $9.0 \times 10^{-8} \mathrm{mrem}\left(9.0 \times 10^{-7} \mu \mathrm{Sv}\right)$. Attachment 1 provides the dose estimates for each individual source. 


\section{References}

LandScan ${ }^{\mathrm{TM}}$ Global Population Database, 2010,

http://www.ornl.gov/sci/landscan/landscan_documentation.shtml

EPA 1989: U.S. Environmental Protection Agency, National Emission Standard for Emissions of Radionuclides Other Than Radon From Department of Energy Facilities, 40 CFR Part 61, Subpart H (1989, as amended).

National Council on Radiation Protection and Measurements (NCRP), Principles and Application of Collective Dose in Radiation Protection, NCRP Report No. 121 (1995).

USDA 2007. United States Department of Agriculture. The Census of Agriculture. 2007 Census Publications. Volume 1, Chapter 2, County Level Data. Table 1 and Table 11. http://www.agcensus.usda.gov/Publications/2007/Full_Report/Volume_1,_Chapter_2_C ounty_Level/California/index.asp (accessed May 19, 2009). 


\section{Errata}

In the 2010 NESHAPs report, page 6-1 (first paragraph) stated for collective dose "0.57 person-rem ( 0.0057 person-Sv)"; this should have read "0.56 person-rem $(0.0056$ person-Sv)". 


\section{Attachments}




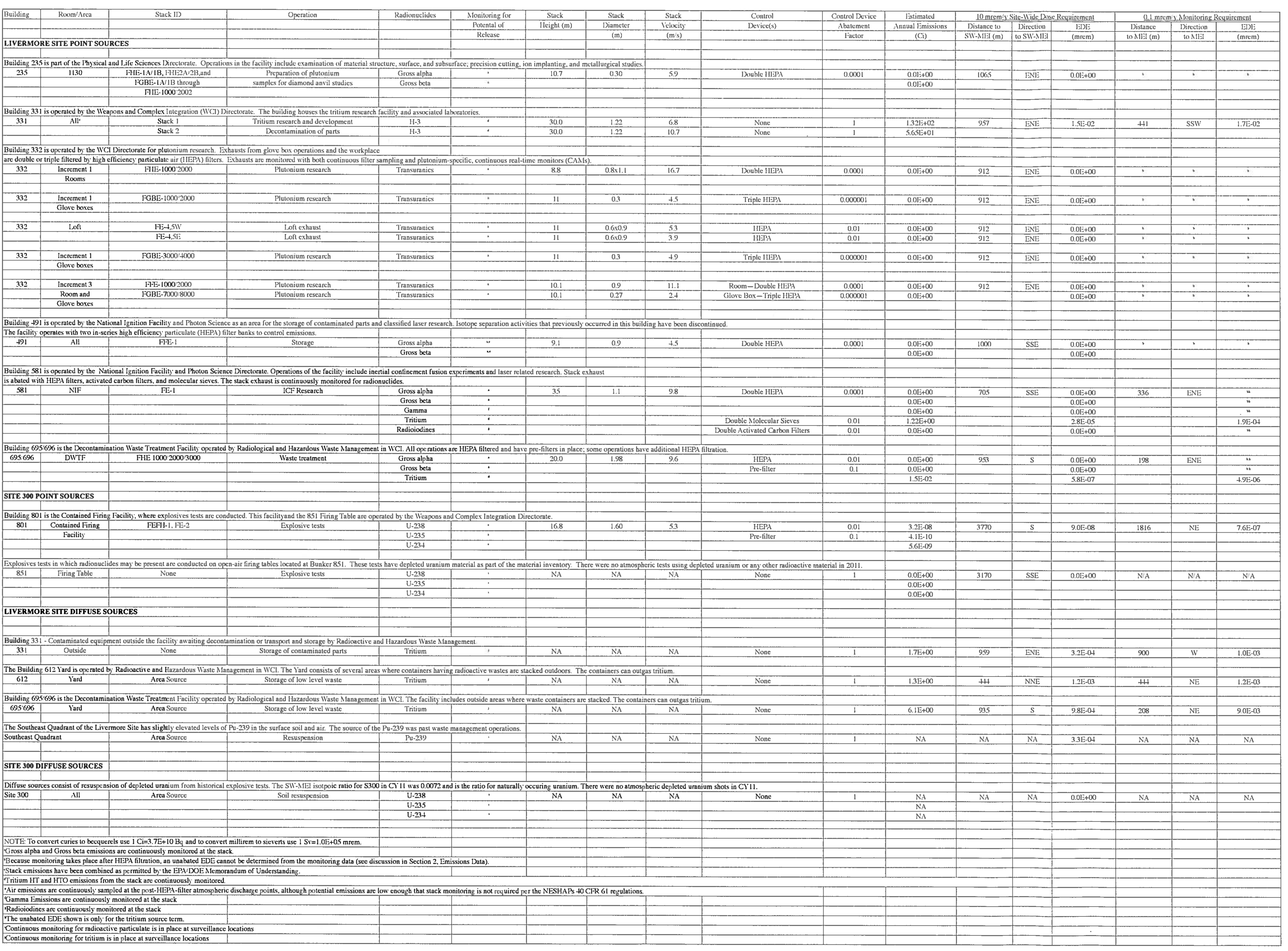




\section{ATTACHMENT 2: METEOROLOGICAL DATA}

CAP88-PC requires meteorological data in the form of joint-frequency distributions of wind direction and wind speed organized by stability category. The first line of the file contains three hexadecimal file marks that are ignored by CAP88-PC. The second line is the average wind speed and is not used by CAP88-PC. The third line contains the wind frequency totals (in format 6.4, i.e., 6 places per value, 4 after the decimal place) beginning at the direction, $\mathrm{N}$, and cycling counterclockwise through the wind directions. The following 8 lines contain the reciprocal average (or harmonic average) wind speed (in format 5.3) for each class of wind direction and stability. Each row is a stability class, $A$ through $\mathrm{G}$, and each "column" is the wind direction, again beginning at $\mathrm{N}$ and cycling counterclockwise. The next 8 lines are the arithmetic average wind speeds, in the same format as the reciprocal average. The final 16 lines are the frequencies of stability class, with the columns being the stability class and the rows the wind direction, beginning with $\mathrm{N}$ and cycling counterclockwise. The wind file for the Livermore site was created from 2011 data collected from the Livermore site meteorological tower at the 10-m level; the wind file for Site 300 was created from 2011 data collected from the Site 300 meteorological tower at the $10-\mathrm{m}$ level.

\section{A.2.1 LIVERMORE SITE TOWER}

\begin{tabular}{|c|c|c|c|c|c|c|}
\hline \multicolumn{7}{|l|}{2.31588} \\
\hline \multicolumn{7}{|c|}{$\begin{array}{l}0.05970 .03130 .03250 .04890 .05010 .03950 .05720 .06920 .04890 .02080 .01510 .01940 .08010 .12630 .14980 .1512 \\
2.1101 .0001 .0001 .0001 .4871 .0001 .4902 .1292 .1231 .6131 .7431 .7462 .1122 .2092 .1001 .590\end{array}$} \\
\hline \multicolumn{7}{|c|}{1.6331 .7301 .0001 .1911 .4601 .4562 .0692 .4822 .3111 .6481 .5041 .7682 .8172 .6142 .8102 .410} \\
\hline \multicolumn{7}{|c|}{2.2842 .2451 .1581 .9651 .2941 .3772 .2102 .9552 .5151 .5161 .1801 .5733 .1292 .9503 .0723 .122} \\
\hline \multicolumn{7}{|c|}{2.2912 .2871 .3330 .8710 .9451 .1421 .7082 .4522 .6141 .2750 .9491 .0832 .5712 .6853 .1043 .185} \\
\hline \multicolumn{7}{|c|}{ 1.4271.1650.9120.7960.8430.9331.1581.0650.9521.1500.8701.0971.3741.7221.7451.733 } \\
\hline \multicolumn{7}{|c|}{ 1.1170.7850.6870.6180.6040.6130.6620.6050.7290.7260.7480.7620.9591.1981.1581.269 } \\
\hline \multicolumn{7}{|c|}{0.0000 .0000 .0000 .0000 .0000 .0000 .0000 .0000 .0000 .0000 .0000 .0000 .0000 .0000 .0000 .000} \\
\hline \multicolumn{7}{|c|}{ 2.1101.0001.0001.0001.5191.0001.6652.2322.3771.7351.8111.7952.2342.3042.2482.240 } \\
\hline \multicolumn{7}{|c|}{1.8492 .4891 .0001 .5501 .5541 .5672 .1832 .8512 .8132 .0661 .6642 .0283 .1712 .9553 .1853 .101} \\
\hline \multicolumn{7}{|c|}{ 3.1672.9721.1582.0971.5951.5442.5043.2183.2382.2311.3892.0713.5583.3823.6033.829 } \\
\hline \multicolumn{7}{|c|}{ 3.2713.3791.7311.1571.0111.3662.0484.1374.9532.9971.1941.8123.2053.3033.5513.726 } \\
\hline \multicolumn{7}{|c|}{ 1.7371.4531.2220.9100.9581.1721.4891.4811.3211.7070.9411.5131.6562.0381.9841.990 } \\
\hline \multicolumn{7}{|c|}{1.2820 .8970 .7810 .6960 .6760 .6940 .7580 .6790 .8330 .7810 .8380 .9081 .1941 .3891 .3491 .417} \\
\hline \multicolumn{7}{|c|}{ 0.0000.0000.0000.0000.0000.0000.0000.0000.0000.0000.0000.0000.0000.0000.0000.000 } \\
\hline 0.0019 & 0.0154 & 0.0366 & 0.1792 & 0.2948 & 0.4721 & 0.0000 \\
\hline 0.0000 & 0.0110 & 0.0404 & 0.1691 & 0.1544 & 0.6250 & 0.0000 \\
\hline 0.0000 & 0.0000 & 0.0035 & 0.0495 & 0.1166 & 0.8304 & 0.0000 \\
\hline 0.0000 & 0.0047 & 0.0235 & 0.0212 & 0.1506 & 0.8000 & 0.0000 \\
\hline 0.0046 & 0.0138 & 0.0183 & 0.0528 & 0.1491 & 0.7615 & 0.0000 \\
\hline 0.0000 & 0.0320 & 0.0523 & 0.0959 & 0.1628 & 0.6570 & 0.0000 \\
\hline 0.0100 & 0.1064 & 0.2390 & 0.1667 & 0.1486 & 0.3293 & 0.0000 \\
\hline 0.0183 & 0.1395 & 0.3555 & 0.2625 & 0.0963 & 0.1279 & 0.0000 \\
\hline 0.0165 & 0.1388 & 0.2424 & 0.3388 & 0.0918 & 0.1718 & 0.0000 \\
\hline 0.0331 & 0.1878 & 0.2044 & 0.2541 & 0.1160 & 0.2044 & 0.0000 \\
\hline 0.1298 & 0.1908 & 0.2901 & 0.1679 & 0.0916 & 0.1298 & 0.0000 \\
\hline 0.0651 & 0.2249 & 0.2426 & 0.1361 & 0.1243 & 0.2071 & 0.0000 \\
\hline 0.0617 & 0.2611 & 0.3615 & 0.1750 & 0.0803 & 0.0603 & 0.0000 \\
\hline 0.0646 & 0.2866 & 0.2530 & 0.2066 & 0.1146 & 0.0746 & 0.0000 \\
\hline 0.0169 & 0.1236 & 0.2011 & 0.3622 & 0.1688 & 0.1274 & 0.0000 \\
\hline 0.0023 & 0.0297 & 0.0920 & 0.4327 & 0.2236 & 0.2198 & 0.0000 \\
\hline
\end{tabular}




\section{A.2.2 SITE 300 TOWER}

\begin{tabular}{|c|c|c|c|c|c|c|}
\hline \multicolumn{7}{|l|}{5.59977} \\
\hline \multirow{2}{*}{\multicolumn{7}{|c|}{$\begin{array}{l}0.03600 .04000 .03340 .01810 .01250 .01700 .01930 .03410 .06190 .10760 .09560 .07260 .07070 .13320 .20790 .0402 \\
1.0001 .0001 .00034471 .00028573 .2133 .00827871 .0003 .2401 .0001 .00024401 .0001 .000\end{array}$}} \\
\hline & & & & & & \\
\hline \multicolumn{7}{|c|}{ 2.5911.9022.3982.0612.9682.1582.4582.3512.9752.7493.2463.4753.3243.7413.8033.116 } \\
\hline \multicolumn{7}{|c|}{ 3.3162.5132.5402.5392.3032.2972.0242.2843.0013.6183.7183.6014.3555.1696.2762.819 } \\
\hline \multicolumn{7}{|c|}{ 3.8084.0064.7703.0342.1261.9411.5831.9043.8595.2434.6624.2305.0556.5908.1963.907 } \\
\hline \multicolumn{7}{|c|}{2.2212 .0471 .8531 .5591 .4031 .3851 .2801 .2011 .5911 .6371 .8492 .0292 .0012 .4392 .2461 .925} \\
\hline \multicolumn{7}{|c|}{ 1.4031.3591.2591.1691.0590.9730.9401.0631.0911.3181.3711.3641.3231.3631.3091.295 } \\
\hline \multicolumn{7}{|c|}{ 0.0000.0000.0000.0000.0000.0000.0000.0000.0000.0000.0000.0000.0000.0000.0000.000 } \\
\hline \multicolumn{7}{|c|}{1.0001 .0001 .0003 .4471 .0002 .8853 .2633 .0272 .7891 .0003 .3151 .0001 .0002 .4401 .0001 .000} \\
\hline \multicolumn{7}{|c|}{ 2.8391.9052.4202.1893.2312.6152.6902.6613.3763.2513.7783.9913.7644.1804.1093.457 } \\
\hline \multicolumn{7}{|c|}{3.8153 .2983 .0963 .1402 .7472 .7542 .3162 .7003 .5694 .3714 .2514 .5095 .3396 .3728 .4643 .340} \\
\hline \multicolumn{7}{|c|}{ 4.9735.2236.9385.3903.2872.3122.0062.7935.6777.1995.6994.8866.0677.6399.9584.689 } \\
\hline \multicolumn{7}{|c|}{ 2.4302.3362.1671.7031.6201.5051.3731.3961.7281.8992.0942.2762.3732.8512.5592.378 } \\
\hline \multicolumn{7}{|c|}{ 1.5561.4561.3661.2631.1711.0561.0351.1591.1691.4181.5051.4671.4331.4771.4671.402 } \\
\hline \multicolumn{7}{|c|}{0.0000 .0000 .0000 .0000 .0000 .0000 .0000 .0000 .0000 .0000 .0000 .0000 .0000 .0000 .0000 .000} \\
\hline 0.0000 & 0.0096 & 0.0382 & 0.4650 & 0.3280 & 0.1592 & 0.0000 \\
\hline 0.0000 & 0.0057 & 0.0659 & 0.5501 & 0.2607 & 0.1175 & 0.0000 \\
\hline 0.0000 & 0.0206 & 0.0893 & 0.5636 & 0.1959 & 0.1306 & 0.0000 \\
\hline 0.0063 & 0.0570 & 0.1519 & 0.4051 & 0.1772 & 0.2025 & 0.0000 \\
\hline 0.0000 & 0.1101 & 0.2752 & 0.2569 & 0.1743 & 0.1835 & 0.0000 \\
\hline 0.0270 & 0.2500 & 0.3581 & 0.1081 & 0.1014 & 0.1554 & 0.0000 \\
\hline 0.0298 & 0.3988 & 0.3155 & 0.1190 & 0.0774 & 0.0595 & 0.0000 \\
\hline 0.0135 & 0.3906 & 0.3434 & 0.1178 & 0.0572 & 0.0774 & 0.0000 \\
\hline 0.0037 & 0.3278 & 0.4037 & 0.2037 & 0.0333 & 0.0278 & 0.0000 \\
\hline 0.0000 & 0.1002 & 0.3401 & 0.4840 & 0.0501 & 0.0256 & 0.0000 \\
\hline 0.0024 & 0.0420 & 0.1945 & 0.5786 & 0.1164 & 0.0660 & 0.0000 \\
\hline 0.0000 & 0.0221 & 0.1485 & 0.5924 & 0.1627 & 0.0742 & 0.0000 \\
\hline 0.0000 & 0.0308 & 0.1169 & 0.5958 & 0.1688 & 0.0877 & 0.0000 \\
\hline 0.0009 & 0.0138 & 0.0844 & 0.7829 & 0.0810 & 0.0370 & 0.0000 \\
\hline 0.0000 & 0.0077 & 0.0640 & 0.8609 & 0.0430 & 0.0243 & 0.0000 \\
\hline 0.0000 & 0.0200 & 0.0457 & 0.5229 & 0.2943 & 0.1171 & 0.0000 \\
\hline
\end{tabular}

\section{ATTACHMENT 3: POPULATION DATA}

The source of the geographic population distribution data used for this report is Oak Ridge National Laboratory (ORNL) LandScan ${ }^{T M} 2010$ data and ESRI ARCMAP software. The data are placed into an annular grid that is created from sixteen 22.5-degree sectors centered on the cardinal wind directions and five distances spaced at $16 \mathrm{~km}$ to a total $80-\mathrm{km}$ radius. In deriving the population for each site, the ORNL data set is input into ESRI ARCMAP with the 80-km grid for the Livermore site centered at $37.686 \mathrm{~N}$ latitude, 121.7045 W longitude (near the center of the site) and Site 300 centered at the 52-m meteorological tower located at $37.675 \mathrm{~N}$ latitude, $-121.541 \mathrm{~W}$ longitude. The first line of the input file is informational. Distances are shown in the second row. Population data begin in the third row starting with direction, $N$. There are 20 spaces reserved for each direction no matter how many are used; i.e., the next direction, NNW, starts approximately half-way through the fifth row, 21 values after the first value. 


\section{A.3.1 LIVERMORE SITE}

\begin{tabular}{|c|c|c|c|c|c|c|c|}
\hline \$ LLNL, 2010 & LIVERMORE & $\mathrm{LAT}=$ & 37.686 & $\mathrm{LON}=121.70$ & $\mathrm{NSEC}=16$ & NRADS $=5$ & \\
\hline 16.0 & 32.0 & 48. & & 64.0 & 0.0 & & \\
\hline 4603 . & 50952. & 51137. & 7792 . & 1670 . & 0 . & 0 . & 0 . \\
\hline 0 . & 0 . & 0 . & 0 . & 0 . & 0 . & 0 . & 0 . \\
\hline 0 . & 0 . & 0 . & 0 . & 8306 . & 2745 . & 139294 . & 316. \\
\hline 205660 . & 0 . & 0 . & 0 . & 0 . & 0 . & 0 . & 0 . \\
\hline 0 . & 0 . & 0 . & 0 . & 0 . & 0 . & 0 . & 0 . \\
\hline 6524 . & 30164 . & 303953 . & 126916 . & 115478 . & 0 . & 0 . & 0 . \\
\hline 0 . & 0 . & 0 . & 0 . & 0 . & 0 . & 0 . & 0 . \\
\hline 0 . & 0 . & 0 . & 0 . & 25489 . & 107100 . & 223714 . & 757007 . \\
\hline 248993 . & 0 . & 0 . & 0 . & 0 . & 0 . & 0 . & 0 . \\
\hline 0 . & 0 . & 0 . & 0 . & 0 . & 0 . & 0 . & 0 . \\
\hline 71906. & 107349 . & 333955 . & 451185 . & 501855 . & 0 . & 0 . & 0 . \\
\hline 0 . & 0 . & 0 . & 0 . & 0 . & 0 . & 0 . & 0 . \\
\hline 0 . & 0 . & 0 . & 0 . & 16937. & 157636 . & 148012 . & 339533. \\
\hline 19998. & 0 . & 0 . & 0 . & 0 . & 0 . & 0 . & 0 . \\
\hline 0 . & 0 . & 0 . & 0 . & 0 . & 0 . & 0 . & 0 . \\
\hline 1183. & 114211 . & 412258 . & 157789 . & 4542 . & 0 . & 0 . & 0 . \\
\hline 0 . & 0 . & 0 . & 0 . & 0 . & 0 . & 0 . & 0 . \\
\hline 0 . & 0 . & 0 . & 0 . & 408 . & 23676 . & 752857 . & 280018 . \\
\hline 49939. & 0 . & 0 . & 0 . & 0 . & 0 . & 0 . & 0 . \\
\hline 0 . & 0 . & 0 . & 0 . & 0 . & 0 . & 0 . & 0 . \\
\hline 184. & 14. & 55832 . & 71355 . & 73855 . & 0 . & 0 . & 0 . \\
\hline 0 . & 0 . & 0 . & 0 . & 0 . & 0 . & 0 . & 0 . \\
\hline 0 . & 0 . & 0 . & 0 . & 353 . & 3 . & 52. & 22 . \\
\hline 1300 . & 0 . & 0 . & 0 . & 0 . & 0 . & 0 . & 0 . \\
\hline 0 . & 0 . & 0 . & 0 . & 0 . & 0 . & 0 . & 0 . \\
\hline 227 . & 52. & 26 . & 427 . & 14103. & 0 . & 0 . & 0 . \\
\hline 0 . & 0 . & 0 . & 0 . & 0 . & 0 . & 0 . & 0 . \\
\hline 0 . & 0 . & 0 . & 0 . & 1589 . & 130. & 1345 . & 20868 . \\
\hline 74302 . & 0 . & 0 . & 0 . & 0 . & 0 . & 0 . & 0 . \\
\hline 0 . & 0 . & 0 . & 0 . & 0 . & 0 . & 0 . & 0 . \\
\hline 285 . & 24193 . & 4631 . & 192319. & 206376 . & 0 . & 0 . & 0 . \\
\hline 0 . & 0 . & 0 . & 0 . & 0 . & 0 . & 0 . & 0 . \\
\hline 0 . & 0 . & 0 . & 0 . & 303 . & 61658 . & 96564 . & 21120 . \\
\hline 4351 . & 0 . & 0 . & 0 . & 0 . & 0 . & 0 . & 0 . \\
\hline 0 . & 0 . & 0 . & 0 . & 0 . & 0 . & 0 . & 0 . \\
\hline 474 . & 5142 . & 117528 . & 287466 . & 21648 . & 0 . & 0 . & 0 . \\
\hline 0 . & 0 . & 0 . & 0 . & 0 . & 0 . & 0 . & 0 . \\
\hline 0 . & 0 . & 0 . & 0 . & 3720 . & 11446 . & 1792 . & 3562 . \\
\hline 31044 . & 0 . & 0 . & 0 . & 0 . & 0 . & 0 . & 0 . \\
\hline 0 . & 0 . & 0 . & 0 . & 0 . & 0 . & 0 . & 0 . \\
\hline 0 . & 0 . & 0 . & 0 . & 0 . & 0 . & 0 . & 0 . \\
\hline 0 . & 0 . & 0 . & 0 . & 0 . & 0 . & 0 . & 0 . \\
\hline 0 . & 0 . & 0 . & 0 . & 0 . & 0 . & 0 . & 0 . \\
\hline 0 . & 0 . & 0 . & 0 . & 0 . & 0 . & 0 . & 0 . \\
\hline 0 . & 0 . & 0 . & 0 . & 0 . & 0 . & 0 . & 0 . \\
\hline 0 . & 0 . & 0 . & 0 . & 0 . & 0 . & 0 . & 0 . \\
\hline 0 . & 0 . & 0 . & 0 . & 0 . & 0 . & 0 . & 0 . \\
\hline 0 . & 0 . & 0 . & 0 . & 0 . & 0 . & 0 . & 0 . \\
\hline 0 . & 0 . & 0 . & 0 . & 0 . & 0 . & 0 . & 0 . \\
\hline 0 . & 0 . & 0 . & 0 . & 0 . & 0 . & 0 . & 0 . \\
\hline
\end{tabular}




\section{A.3.2 SITE 300}

\begin{tabular}{|c|c|c|c|c|c|c|c|}
\hline $\begin{array}{c}\text { LLNL， } 2010 \\
16.0\end{array}$ & $\begin{array}{r}\text { LIVERMORE } \\
32.0\end{array}$ & $\begin{array}{r}\mathrm{LAT} \\
4\end{array}$ & 7.67502 & $\begin{array}{l}\mathrm{LON}=121.54 \\
64.0\end{array}$ & $\begin{array}{l}\text { NSEC }=16 \\
80.0\end{array}$ & $\operatorname{RADS}=5$ & \\
\hline 5615 . & 3457 & 1896. & 4880 . & 12496 & 0 . & 0 . & 0 . \\
\hline 0 . & 0 . & 0 . & 0 . & 0 . & 0 . & 0 . & 0 . \\
\hline 0 . & 0 . & 0 . & 0 . & 401. & 20707 . & 124388 & 6373. \\
\hline 75585 . & 0 . & 0 . & 0 . & 0 . & 0 . & 0 . & 0 . \\
\hline 0. & 0 . & 0 . & 0 . & 0 . & 0 . & 0 . & 0 . \\
\hline 26 . & 145. & 64103. & 269493 . & 148777 . & 0 . & 0 . & 0 . \\
\hline 0 . & 0 . & 0 . & 0 . & 0 . & 0 . & 0 . & 0 . \\
\hline 0 . & 0 . & 0 . & 0 . & 5032 . & 18097. & 125359 . & 317499 . \\
\hline 590429 . & 0 . & 0 . & 0 . & 0 . & 0 . & 0 . & 0 . \\
\hline 0 & 0 . & 0 . & 0 . & 0 . & 0 . & 0 . & 0 . \\
\hline 10536. & 131506. & 209722 . & 366132 . & 899386 . & 0 . & 0 . & 0 . \\
\hline 0. & 0 & 0 . & 0 & 0 . & 0 . & 0 . & 0 . \\
\hline 0 . & 0 . & 0 . & 0 . & 288. & 1351. & 265880 . & 336275 . \\
\hline 168555. & 0 . & 0 . & 0 . & 0 . & 0 & 0 & 0 \\
\hline 0 & 0 . & 0 . & 0 . & 0 . & 0 . & 0 . & 0 . \\
\hline 50 . & 22 . & 437134 . & 819824 . & 14140 . & 0 . & 0 . & 0 . \\
\hline 0 . & 0 . & 0 . & 0 . & 0 . & 0 . & 0 . & 0 . \\
\hline 0 . & 0 . & 0 . & 0 . & 26 . & 1. & 88891 . & 201189 . \\
\hline 15024 . & 0 . & 0 . & 0 . & 0 . & 0 . & 0 . & 0 . \\
\hline 0 . & 0 . & 0 . & 0 . & 0 . & 0 . & 0 . & 0 . \\
\hline 13. & 43. & 24 . & 34136 . & 66497. & 0 . & 0 . & 0 . \\
\hline 0 . & 0 . & 0 . & 0 . & 0 . & 0 . & 0 . & 0 . \\
\hline 0 . & 0 . & 0 . & 0 . & 2 . & 6. & 33. & 1 . \\
\hline 424 . & 0 . & 0 . & 0 . & 0 . & 0 . & 0 . & 0 . \\
\hline 0 . & 0 . & 0 . & 0 . & 0 . & 0 . & 0 . & 0 . \\
\hline 60. & 2 . & 2680 . & 10933. & 9207. & 0 . & 0 . & 0 . \\
\hline 0 . & 0 . & 0 . & 0 . & 0 . & 0 . & 0 . & 0 . \\
\hline 0 . & 0 . & 0 . & 0 . & 165. & 868 . & 19088. & 57566 . \\
\hline 67281. & 0 . & 0 . & 0 . & 0 . & 0 . & 0 & 0 \\
\hline 0 & 0 . & 0 . & 0 . & 0 . & 0 . & 0 . & 0 . \\
\hline 1021. & 2270 . & 139601 . & 234692 . & 13111. & 0 . & 0 . & 0 . \\
\hline 0 . & 0 . & 0 & 0 . & 0 . & 0 . & 0 . & 0 . \\
\hline 0 . & 0 . & 0 . & 0 . & 28653 . & 45774 . & 35505 . & 12505 . \\
\hline 1051. & 0 . & 0 . & 0 . & 0 . & 0 . & 0 & 0 \\
\hline 0 & 0 . & 0 . & 0 . & 0 . & 0 . & 0 . & 0 . \\
\hline 50245 . & 17601. & 165338 . & 8051. & 7348 . & 0 . & 0 . & 0 . \\
\hline 0 . & 0 . & 0 . & 0 . & 0 . & 0 . & 0 . & 0 . \\
\hline 0 . & 0 . & 0 . & 0 . & 2686 . & 715 . & 199143. & 79849 . \\
\hline 31433. & 0 . & 0 . & 0 . & 0 . & 0 . & 0 . & 0 . \\
\hline 0 . & 0 . & 0 . & 0 . & 0 . & 0 . & 0 . & 0 . \\
\hline 0 . & 0 . & 0 . & 0 . & 0 . & 0 . & 0 . & 0 . \\
\hline 0 . & 0 . & 0 . & 0 . & 0 . & 0 . & 0 . & 0 . \\
\hline 0 . & 0 . & 0 . & 0 . & 0 . & 0 . & 0 . & 0 . \\
\hline 0 . & 0 . & 0 . & 0 . & 0 . & 0 . & 0 . & 0 . \\
\hline 0 . & 0 . & 0 . & 0 . & 0 . & 0 . & 0 . & 0 . \\
\hline 0 . & 0 . & 0 . & 0 . & 0 . & 0 . & 0 . & 0 . \\
\hline 0 . & 0 . & 0 . & 0 . & 0 . & 0 . & 0 . & 0 . \\
\hline 0 . & 0 . & 0 . & 0 . & 0 . & 0 . & 0 . & 0 . \\
\hline 0 . & 0 . & 0 . & 0 . & 0 . & 0 . & 0 . & 0 . \\
\hline 0 . & 0 . & 0 . & 0 . & 0 . & 0 . & 0 . & 0 . \\
\hline
\end{tabular}

